\title{
Common Mechanisms Underlying Epileptogenesis and the Comorbidities of Epilepsy
}

\author{
Andrey Mazarati ${ }^{1}$ and Raman Sankar ${ }^{1,2}$ \\ ${ }^{1}$ Department of Pediatrics, Division of Pediatric Neurology, David Geffen School of Medicine at UCLA, \\ UCLA Medical Center, Los Angeles, California 90095-1752 \\ ${ }^{2}$ Department of Neurology, David Geffen School of Medicine at UCLA, UCLA Medical Center, \\ Los Angeles, California 90095-1752 \\ Correspondence: rsankar@ucla.edu
}

The importance of comorbidities in determining the quality of life of individuals with epilepsy and their families has received increasing attention in the past decade. Along with it has come a recognition that in some individuals, certain comorbidities may have preexisted, and may have contributed to their developing epilepsy. Many mechanisms are capable of interconnecting different dysfunctions that manifest as distinct disorders, often diagnosed and managed by different specialists. We review the human data from the perspective of epidemiology as well as insights gathered from neurodiagnostic and endocrine studies. Animal studies are reviewed to refine our mechanistic understanding of the connections, because they permit the narrowing of variables, which is not possible when studying humans.

\begin{abstract}
The epilepsies represent a group of brain disorders in which the primary symptoms, seizures, are generated by an abnormal balance between excitation and inhibition. Complex mechanisms underlie the evolution of abnormal neuronal and network excitability as well as enhanced synchronization of neuronal populations (Engel 2013). The medications used to treat epilepsy at the present time are designed to limit excitation and/or enhance inhibition (Elger and Schmidt 2008). In recent times, those of us concerned with caring for people with epilepsy (PWE) have become sensitized to the impact of psychiatric comorbidities on the quality of life of our patients (Hermann et al. 2000a; Johnson et al. 2004). What is the relationship
\end{abstract}

between epilepsy and the well-described psychiatric comorbidities? As early as around 400 BC, Hippocrates observed that "melancholics ordinarily become epileptics, and epileptics, melancholics" (Lewis 1934; Temkin 1971). Epidemiologic evidence is accumulating to validate that view of a reciprocal relationship, showing a higher prevalence of psychiatric disorders preceding the onset of seizure disorders (Hesdorffer et al. 2000, 2004, 2006, 2012; Chang et al. 2011; Adelow et al. 2012). Recent experiments in the laboratory have recaptured that clinical picture; when rats selectively bred for vulnerability or resilience to depression-like phenotypes were subjected to pilocarpine administration (a model of status epilepticus in-

Editors: Gregory L. Holmes and Jeffrey L. Noebels

Additional Perspectives on Epilepsy: The Biology of a Spectrum Disorder available at www.perspectivesinmedicine.org

Copyright (C) 2016 Cold Spring Harbor Laboratory Press; all rights reserved

Advanced Online Article. Cite this article as Cold Spring Harb Perspect Med doi: 10.1101/cshperspect.a022798 
duced epileptogenesis), the rats with the depression-like phenotype showed a shorter latency to limbic seizures, and half of those rats developed spontaneous limbic motor seizures although none of the depression-resistant rats did (Epps et al. 2012). The rats with the depression-like phenotype also had a lower threshold to electroshock seizures and showed a lower final hippocampal kindling threshold. Likewise, repeatedly stressed rats reached the fully kindled state with fewer amygdala stimulations than nonstressed animals (Jones et al. 2013). This review will explore the shared pathogenic mechanisms that may link these brain disorders, with emphasis on the comorbidity of depression, and will also evaluate the available findings in terms of novel targets for the amelioration of these multifaceted disorders of brain function.

\section{FINDINGS IN THE EPIDEMIOLOGIC LITERATURE}

From the perspective of the epileptologist, depression has been seen as an important comorbidity that needs to be addressed to optimally manage PWE. Increased prevalence of depression has been described in both pediatric (Ettinger et al. 1998; Oguz et al. 2002; Caplan et al. 2005) and adult (Hermann et al. 2000b; Piazzini et al. 2001; Kanner 2005) patients. The finding from a Swedish study that preexisting depressive disorders were seen seven times more frequently among patients with new-onset epilepsy than age- and sex-matched controls (Forsgren and Nystrom 1990) was both surprising and intriguing. A decade later, Hesdorffer and colleagues (Hesdorffer et al. 2000) reported that, in adults aged 55 years and older from Omstead County, Minnesota, at the time of onset of their epilepsy, diagnosis of depression was 3.7 times more frequent than among controls. The association was greater for focal epilepsy in both those studies. Another population-based study, conducted in Iceland, revealed that children with the diagnosis of attention-deficit hyperactivity disorder (ADHD) of the inattentive type were 3.5 times more likely to develop epilepsy than controls (Hesdorffer et al. 2004). In that same Icelandic population, a major depres- sive episode as defined in the Diagnostic and Statistical Manual of Mental Disorders, 4th ed., was associated with a 1.7-fold increased risk of developing epilepsy (Hesdorffer et al. 2006), whereas attempted suicide was 5.1 times more common among controls. A two- to fourfold increased frequency of anxiety, depression, suicidality, and psychosis were identified in a study in the United Kingdom during the 3 years preceding the onset of epilepsy compared with controls (Hesdorffer et al. 2012). Very similar findings emerged in a Swedish study (Adelow et al. 2012) that compared the risk of developing epilepsy among patients who had been hospitalized for a psychiatric disorder to a group of controls matched for gender and year of diagnosis; the age-adjusted overall odds ratio (OR) of 2.7 was very similar for major depressive disorder (MDD, OR of 2.5), bipolar disorder (OR of 2.7), anxiety disorder (OR of 2.7), and suicide attempt (OR of 2.6). Investigators in Taiwan (Chang et al. 2011) identified a sixfold higher risk for developing epilepsy among patients diagnosed with schizophrenia compared with controls.

An obvious concern in the interpretation of such data is the potential impact of the pharmacotherapy of psychiatric conditions, because many of these agents are accompanied by warnings regarding the potential for seizures (Harden and Goldstein 2012). However, a meta-analysis of randomized, placebo-controlled, multicenter trials of selective serotonin reuptake inhibitors (SSRIs) and serotoninnorepinephrine reuptake inhibitors submitted to the Food and Drug Administration (FDA) during 1985 to 2004 involving 75,873 patients actually found a lower incidence of seizures among depressed patients randomized to the antidepressant arm compared with placebo (standardized incidence ratio $=0.48 ; 95 \% \mathrm{CI}$, 0.36-0.61), whereas patients assigned to placebo experienced a 19-fold higher incidence of seizures than the published incidence in the community nonpatient samples (Alper et al. 2007). Indeed, this is consistent with reports of small series in which SSRIs seemed to exert an anticonvulsant effect in PWE. In a cohort of 17 medically refractory patients with focal sei- 
zures with secondary generalization treated with fluoxetine, six patients experienced a complete disappearance of their daily seizure, whereas the others experienced an average reduction of $30 \%$ of their seizures (Favale et al. 1995). All of the patients had received a $20 \mathrm{mg}$ dose, which is quite modest. Nine out of 11 patients with uncontrolled epilepsy and without depression responded to citalopram therapy with $>50 \%$ reduction in seizures (Favale et al. 2003). These findings are in concordance with findings in animal models described below. On the other hand, atypical antipsychotic medications, clozapine, olanzapine, and to a lesser extent, quetiapine, when given to patients with psychotic disorders, seemed to be associated with a higher incidence of seizures than placebo (Alper et al. 2007). The pattern emerging from the findings above is that enhancing the serotonergic tone is ameliorative of seizures as well as depression while limiting dopaminergic tone likely lowers seizure threshold even as it may be of benefit in reducing psychotic symptoms.

To explore the possibility of primary psychiatric disease influencing the epileptogenic process, this work will review several known pathogenic mechanisms. These include (1) aberrant neurotransmitter systems, (2) disturbances in opioid secretion and action, (3) a brittle or twitchy hypothalamic-pituitary-adrenal (HPA) axis causing excessive glucocorticoid signaling with downstream effects on neurotransmitters like serotonin and producing excessive cell loss and atrophy in vulnerable brain regions, and, (4) the role played by mechanisms of neuroinflammation.

\section{FINDINGS IN HUMANS}

\section{Disturbances in Neurotransmitters}

\section{Serotonin (5-HT)}

The serotonin hypothesis of depression (Coppen 1967) dates back to the 1960s and postulated a deficit in 5-HT as a primary cause of depression, and has been an important driver of antidepressant drug design. Its present status, seen in the perspectives of advances in neuroimaging, genetics, and other new knowledge is reviewed concisely (Albert and Benkelfat 2012; Albert et al. 2012). The role of 5-HT1A receptors have been studied in humans using positron emission tomography (PET) using ${ }^{18} \mathrm{~F}$ or

${ }^{11} \mathrm{C}$-labeled ligands that bind avidly to 5-HT1A receptors. These studies involving patients with MDD and temporal lobe epilepsy (TLE) reveal comparable decreased 5-HT1A receptor binding in both these disorders in the hippocampus, amygdala, cingulate gyrus, insula, and the raphe nucleus (Sargent et al. 2000; Toczek et al. 2003; Theodore et al. 2006; Hasler et al. 2007). A PET study using a ligand for the 5-HT transporter showed diminished transporter binding in the insula and fusiform gyrus in a compensatory manner such that maintenance of a higher levels of 5-HT at sites that have fewer 5-HT1A may be supported (Martinez et al. 2013). The association between depressive symptoms in TLE patients and central serotonergic pathways in sites such as the raphe nucleus, insula, the cingulate gyrus, and the epileptic hippocampus was confirmed by studies (Lothe et al. 2008). Overall, functional neuroimaging studies involving ligand binding to 5-HT1A receptors or the 5-HT transporter suggest a deficit in serotonergic tone such that depression and epilepsy could coexist, and indeed one disorder could influence the other on this basis.

\section{Glutamate and $\gamma$-Aminobutyric Acid (GABA)}

As stated earlier, an operational view of epilepsy for developing therapeutics has posited the disorder as an imbalance between excitatory glutamatergic tone and inhibitory GABAergic tone, often graphically represented by a scale or a seesaw to suggest the disruption of the critical balance between excitation and inhibition. In a study of patients with MDD, Garakani and associates (Garakani et al. 2013) studied the cerebrospinal fluid (CSF) of patients and found an association of high CSF glutamate and suicidal ideation and lower glutamine posttreatment, which may be correlated with attenuation of dysfunction in the glutamatergic system after antidepressant treatment. A proton magnetic resonance spectroscopy (MRS) found increased cortical glutamate concentrations in frontal and 
occipital lobes (Sanacora et al. 2004). The choice of the anatomic location was dictated by the minimal voxel size requiring loci in which the gray matter from the two hemispheres are aligned in the images. In a small double-blinded series of seven patients with major depression (Berman et al. 2000), patients were randomized to receive two test doses (one dose per day) $0.5 \mathrm{mg} / \mathrm{kg}$ of ketamine, a noncompetitive antagonist of the $N$-methyl-Daspartate (NMDA)-sensitive subtype of the glutamate receptor intravenously or saline; blinded evaluation at $72 \mathrm{~h}$ confirmed significant reduction in the Hamilton Depression Rating Scale. A randomized, double-blind crossover study at the National Institute of Mental Health confirmed those findings and showed that a robust and rapid antidepressant effect resulted from a single intravenous dose of ketamine; onset was discernible within $2 \mathrm{~h}$ after infusion and continued to remain significant for $1 \mathrm{wk}(\mathrm{Za}-$ rate et al. 2006). The immediacy of the effect from NMDA receptor modulation contrasts with the latency for the antidepressant effect experienced with SSRIs. However, antagonists of the NMDA receptor-associated channel blockers like ketamine have been considered to have low "druggability" because of their propensity to produce hallucinations. Nevertheless, the above-described studies support the concept that excessive glutamatergic activity at NMDA receptors could be associated with depression, an imbalance also considered relevant to seizure generation. Functional imaging with 5-HT1A ligands for PET pre- and posttreatment with ketamine in such protocols may provide insights into the relationship of the interaction between glutamatergic and serotonergic signaling.

In keeping with the idea of excitation-inhibition imbalance in epilepsy, a number of studies have shown compromises in GABA systems in a number of psychiatric disorders. Gerner and Hare (1981) found decreased CSF GABA in patients with depression, mania, schizophrenia, and anorexia nervosa, with the lowest levels found in depressed patients. Using proton MRS, Sanacora et al. (1999) determined GABA levels to be decreased in the occipital cortex of depressed patients; they also showed that a treat- ment response to SSRI (Sanacora et al. 2002) and electroconvulsive therapy (Sanacora et al. 2003) were accompanied by increased GABA concentrations measured by the same method. Data from CSF determinations and MRS studies do not permit an easy correlation with network behavior relevant to epileptogenicity or affective disorders. The expression of the GABA-synthesizing enzyme glutamic acid decarboxylase (GAD) isoforms were found decreased in the dentate gyrus and Ammon's horn of patients diagnosed with bipolar disorder (Heckers et al. 2002). Mice deficient in in the $65-\mathrm{kDa}$ isoform of GAD display (-/-) an epileptic phenotype (Kash et al. 1997). The technique of transcranial magnetic stimulation (FDA approved since 2008 for the treatment of major depression) permits a functional assessment of GABA function (Kujirai et al. 1993). A study comparing parameters of cortical excitability in 20 medication-free depressed patients and gender-matched healthy volunteers concluded that intracortical inhibition was reduced in patients with major depression (Bajbouj et al. 2006). The measure of cortical inhibition used in that study had previously been shown to represent monosynaptic GABA-mediated inhibition (Davies et al. 1990). Transcranial magnetic stimulation paradigms known as short-interval cortical inhibition and the cortical silent period provide for an assessment of $\mathrm{GABA}_{\mathrm{A}}$ and $\mathrm{GABA}_{\mathrm{B}}$ receptor-mediated inhibitory neurotransmission, respectively. The findings of Bajbouj et al (2006) of deficits in GABAergic inhibition in major depression have been confirmed by more recent studies (Lefaucheur et al. 2008; Levinson et al. 2010).

\section{Dysfunctions of Opioid Signaling}

The use of opium and its derivatives by man for both medicinal and recreational use dates back to antiquity. The role of endogenous opioid signaling in a variety of neurological disorders, in terms of both pathophysiology and potential therapeutics, has been an area of active research. Distinct physiological results are based on the activation of opiate receptor subtypes. Despite the existence of distinctive anatomic distribu- 
tion of these receptors, the different opioid receptor subtypes, $\mu$-(MOR), $\delta$-(DOR), and $\kappa$ $(\mathrm{KOR})$ are all coupled to inhibitory G-proteins. Activation of theses receptors (e.g., MOR by morphine) results in closure of voltage-sensitive calcium channels, activation of potassium efflux, and reduced cyclic adenosine monophosphate (cAMP), overall leading to reduced neuronal excitability. A significant increase in MOR binding was reported in young suicide victims compared with age-matched controls, but this effect was not discernible in older subjects (Gross-Isseroff et al. 1990). A study of postmortem human brains from 15 suicide victims and controls showed $36-39 \%$ increased density of MOR in the frontal cortex and thalamus of suicide victims compared with controls (Gabilondo et al. 1995). However, a more recent study of suicide victim failed to confirm the above findings (Zalsman et al. 2005).

When mood states were induced, sustained sadness condition was associated with significant deactivation in $\mu$-opioid transmission in the rostral anterior cingulate, ventral pallidum, amygdala, and inferior temporal cortex as reflected by increased MOR available for the selective radiotracer ligand $\left[{ }^{11} \mathrm{C}\right]$-carfentanil (CFN) (Zubieta et al. 2003). This was a demonstration of dynamic changes in $\mu$-opioid transmission in response to an experimentally induced negative affective state. Likewise, induction of a positive mood state resulted in reduced availability of all opioid receptors for $\left[{ }^{11} \mathrm{C}\right]$-diprenorphine (DPN) (Koepp et al. 2009). Together, these data suggest that decreased opioid neurotransmission is associated with a depressed state. It has also been shown that exogenous ligand binding to KOS can produce dysphoria and psychotomimesis (Pfeiffer et al, 1986). However, an antidepressant effect has been shown in animal models treated with antagonists of KOR (Mague et al. 2003) or agonists of DOR (Jutkiewicz 2006).

Patients with TLE have been studied with both $\left[{ }^{11} \mathrm{C}\right]$-CFN, which is MOR selective, and $\left[{ }^{11} \mathrm{C}\right]$-DPN, which is nonselective, as well as $\left[{ }^{18} \mathrm{~F}\right]$-2-fluoro-2-deoxyglucose(FDG) (Mayberg et al. 1991). Carfentanil binding was increased in the temporal neocortex and decreased in the amygdala, along with hypometabolism in the lateral and mesial temporal lobes ipsilateral to the epileptic focus. The lack of change in DPN binding was attributed to likely reduction in number or affinity of DOR and/or KOR. Studies during acute seizures by using reading-induced seizures revealed decreased $\left[{ }^{11} \mathrm{C}\right]$-DPN binding, suggesting that opioid levels increase during seizures (Koepp et al. 1998). Further, a regionally specific increase in overall opioid receptor availability in the postictal period was shown by $\left[{ }^{11} \mathrm{C}\right]$-DPN PET, suggesting that the opioid system may play an important role in seizure control (Hammers et al. 2007). The finding of no overall difference in $\left[{ }^{11} \mathrm{C}\right]$-DPN binding between patients and controls in the anterior temporal lobe when patients are studied during the interictal period was considered to support the concept of a phasic (or dynamic) rather than an enduring or tonic change (Koepp et al. 1998).

\section{Hyperactive HPA Axis}

The demonstration of the failure of a test dose of dexamethasone (DEX) to suppress circulating cortisol level (known as the DEX suppression test) a classic biomarker in MDD, identified in $50 \%$ of patients who meet the criteria for the diagnosis (Nestler et al. 2002). Such a finding has also been reported in patients with TLE (Zobel et al. 2004). Chronic stress and the resultant elevated circulating glucocorticoid levels are associated with tonic inhibition of 5-HT1A mRNA expression in the human as well as rat hippocampus (López et al. 1998). This finding may explain the changes in PET studies with 5-HT1A receptor radio ligand in humans with epilepsy as well as depressive disorders.

A variety of neuropathological changes represented by cell loss and atrophy in both depressive disorders at various limbic sites are likely consequences of chronically elevated cortisol levels (Crossin et al. 1997; Öngür et al. 1998; Bowley et al. 2002; Cotter et al. 2002). The effect on astrocyte proliferation may indirectly impair glutamate reuptake by glial cells and increase synaptic glutamate (Crossin et al. 1997). As previously mentioned, such increases 
in glutamate are relevant to both depression and epilepsy.

\section{Neuroimaging Abnormalities}

Assessment of hippocampal volumes is readily undertaken with magnetic resonance imaging (MRI). Hippocampal volumetric changes are commonly described in patients with depression. Volume loss of $8 \%$ to $19 \%$ has been described by various investigators studying patients with depressive disorders (Sheline et al. 1999; Bremner et al. 2000; Cambell et al. 2004). Shah et al. (1998) documented decreased hippocampal volume as well as gray matter in the temporal neocortex of patients with treatmentresistant depression. The duration of depression correlated inversely with hippocampal volume in women with recurrent depression who were otherwise healthy (Sheline et al. 1999). A study of patients with TLE and varying degrees of depression confirmed an interaction between the two conditions, and those with depression and epilepsy had hippocampal atrophy that could not be explained by the epilepsy alone, based on the lateralization of the epileptic focus (Shamim et al. 2009). In keeping with that observation, Salgado and coworkers performed voxelbased morphometric studies of patients with TLE with or without depression and healthy controls, and found evidence of more gray matter volume loss in patients with mesial TLE and depression (Salgado et al. 2010). Increased amygdalar volumes in patients with TLE and depression have been reported by two groups independently (Tebartz van Elst et al. 1999; Richardson et al. 2007). But these investigators did not confirm an effect of depression on hippocampal volume. The study by Briellmann et al. (2007) did not find a difference in hippocampal volume loss or increased T2 relaxation time ipsilateral to the epileptic focus in patients with or without depression; and in contrast with the above-mentioned studies they found bilateral amygdaloid atrophy rather than increased volume.

Extratemporal abnormalities have been identified in both primary mood disorders and in epilepsy, which suggests dysfunction of a distributed neural network (Sheline et al. 1998; Bremner et al. 2002; Briellmann et al. 2007; Richardson et al. 2007; Kempton et al. 2011). Collectively, these studies reveal structural and functional abnormalities in primary depression as well as TLE, implicating orbital and medial prefrontal cortices, and anatomically related structures within the limbic, striatal, thalamic, and basal forebrain structures.

Voxel-based morphometric analyses have permitted assessment of extratemporal structures in patients with a very high degree of precision and have enabled a number of important findings. In patients with TLE, reduced neocortical thickness and complexity in the frontal poles, frontal operculum, orbitofrontal, lateral temporal, and occipital regions was positively correlated with the duration of epilepsy (Lin et al. 2007). Using similar techniques, Bilevicius and colleagues confirmed the effect of duration, and also found that patients considered to being pharmacoresistant or remitting-relapsing presented a similar pattern of gray matter atrophy, which was more widespread than in patients who were seizure free on medical treatment (Bilevicius et al. 2010). As mentioned earlier, voxel-based morphometric studies have also shown more gray matter volume loss in patients with mesial TLE and depression (Salgado et al. 2010).

Functional studies involving FDG-PET also show bilateral frontal and ipsilateral orbitofrontal hypometabolism in patients with TLE and comorbid depression (Bromfield et al. 1992; Salzberg et al. 2006). Using PET to study regional cerebral blood flow (rCBF), Bench and colleagues (Bench et al. 1993) found anatomic patterns of rCBF alterations that correlated tightly with specific symptom dimensions of depressive illness. All patterns involved regional hypoperfusion, which generally corresponds to areas of hypometabolism. Gilliam et al. noted that the severity of clinical symptoms of depression in refractory focal epilepsy were similar in those with an abnormal FDG-PET compared with those with a normal FDG-PET, rather than the extent of seizure control enjoyed at the time of testing, suggesting the importance of a dysfunctional neuronal network (Gilliam et al. 2004). 
In a subsequent study using MRS to estimate the integrity of the mesial temporal structure by the peak for $N$-acetylaspartate (NAA) the depression scores correlated inversely with the NAA level; that is, depression scores were a function of hippocampal dysfunction, rather than other clinical variables such as day-to-day seizure frequency (Gilliam et al. 2007). Although most imaging studies yield data at one time point in the course of the disease and cannot readily distinguish between cause and consequence of epilepsy and comorbid depression, some studies have provided compelling relationship to early onset and duration of the condition (Lin et al. 2007; Bilevicius et al. 2010).

\section{Role of Inflammation}

Inflammatory markers have been studied in the blood of patients with MDD, as well as resected epileptic tissue. Proinflammatory cytokines, interleukin (IL)-1 $\beta$, IL-2, and IL-6, interferon- $\gamma$, and tumor necrosis factor- $\alpha$ (TNF- $\alpha$ ) are present in the blood of patients with MDD (Krishnadas and Cavanagh 2012). There has even been a proposal to explore cyclooxygenase-2 (COX2 ) inhibitors in major depression (Muller et al. 2011). Association between polymorphisms in the IL-1 $\beta$ promoter revealed a modest association between a haplotype (-311T/T and -511C/ $\mathrm{C}$ ) and recurrent major depression (Borkowska et al. 2011). Two IL-1 $\beta$ gene polymorphisms (rs16944, rs114643) were found to predict a lack of response to SSRIs in $6 \mathrm{wk}$ of treatment (Baune et al. 2010).

Among the various cytokines associated with epilepsy, IL-1 $\beta$ seems to play the most prominent role. Increased frequency of has been found to display proconvulsant properties (see below). An association with IL-1 $\beta$-511T allele in TLE patients who reported an antecedent episode of prolonged febrile convulsion (Kanemoto et al. 2003) convulsions, histopathologic study of resected tissue from humans who underwent epilepsy surgery has revealed an overexpression of IL-1 $\beta$ and its receptor type 1 (IL-1R1) in cortical dysplasia and tuberous sclerosis (Crespel et al. 2002; Ravizza et al. 2006; Boer et al. 2008). Enhancement of excit- ability by IL-1 $\beta$ involves an effect on synaptic glutamate levels by reduction in glutamate uptake by glial cells (Hu et al. 2000) or an enhanced release of glutamate from these cells, mediated by tumor necrosis factor- $\alpha$ (Bezzi et al. 2001). In addition, IL-1 $\beta$ can modify the excitotoxicty induced by $\alpha$-amino-3-hydroxy-5-methyl-4isoxazolepropionic acid (AMPA), which can be modified by TNF- $\alpha$ (Bernardino et al. 2005). Tyrosine phosphorylation of NMDA receptor subunits $2 A$ and $2 B$ by IL- $1 \beta$ enhanced calcium currents mediated by NMDA receptor activation (Viviani et al. 2003). Taken together, inflammatory signaling may have played a part in promoting abnormalities of cerebral development, and the contribution of cytokines to enhanced excitation may be contributory to both human epilepsy and major depression.

\section{FINDINGS FROM ANIMAL MODELS}

Animal models of epilepsy and depression permit a study of the interrelationship without the many confounding factors inherent in studies involving humans. Most prominent among the confounders are the effects of medical treatment, which may obscure certain phenomena by protecting the brain from the severity of the disorder under study. Specific antiseizure medications have been known to exacerbate symptoms of depression, ADHD, or psychosis, whereas others have been found to be beneficial to treat mood disorders. The availability of transgenic animals provides additional advantages in probing mechanisms that is not feasible in the clinical settings.

\section{Aberrations of the HPA Axis}

The regulation of the HPA axis is an important mechanism in maintaining homeostasis and as such both reflects exposure to stress as well contributes to producing symptoms and driving plasticity. Under conditions of stress, the system can switch from an adaptive range to maladaptive. This is usually reflected by abnormally elevated levels of glucocorticoids (generally cortisol in humans, corticosterone in rodents). Experimental chronic stress induced in rodents by 
maternal separation, prolonged physical restraint, cold stress, and sleep-deprivation results in the HPA axis hyperactivity (Edwards et al. 1999; Aisa et al. 2007; Novati et al. 2008) and can be estimated by the elevated plasma corticosterone (CORT) level and/or positive DEX or DEX/CRH tests (Watson et al. 2006). The behavioral response to such experimental stress is seen as increased immobility in the forced swimming test (FST) in rats and in the tail suspension test in mice (behaviors that serve as indicators of hopelessness/despair), as well as the loss of saccharin or sucrose consumption preference (expression of anhedonia) (Richardson 1991; Holmes 2003). These depression-like behaviors can also be induced by glucocorticoid administration (Gregus et al. 2005; Johnson et al. 2006). A genetic mouse model for depression achieved by selective breeding displays the phenotype in the FST, the tail suspension test, and the sucrose preference paradigm also displayed elevated CORT levels and a decreased serotonergic tone (El Yacoubi et al. 2003).

A number of methods used in the laboratory to produce stress as well as administration of exogenous glucocorticoid can facilitate epileptogenesis. Amygdala kindling in rats can be accelerated by repeated physical restraint stress (Jones et al. 2013). Stress induced to neonatal rat pups by repeated separation from dams also facilitated amygdala kindling when the rats were fully grown (Kumar et al. 2011) as well as lowered the threshold for pentylenetetrazole-induced convulsions (Lai et al. 2006). The animals exposed to neonatal stress had an exaggerated CORT response to pilocarpine-induced status epilepticus (Lai et al. 2006). Both episodic and chronic low-dose treatment of rats with CORT can promote kindling epileptogenesis (Karst et al. 1999; Taher et al. 2005; Kumar et al. 2007). In hippocampal slices prepared from rats $1 \mathrm{wk}$ after intrahippocampal kainite injections, $3 \mathrm{~d}$ of high-dose CORT treatment before slice preparation substantially potentiated the epileptiform activity (Talmi et al. 1995); further, this effect was antagonized by a glucocorticoid antagonist, but not a mineralocorticoid antagonist. In a similar manner, when CORTor saline was administered to mice undergoing continu- ous video-EEG monitoring after pilocarpineinduced status epilepticus, the CORT-treated animals showed increased frequency and duration of epileptiform events within the first $24 \mathrm{~h}$ of treatment, and this effect persisted for up to 2 wk following termination of CORT injections (Castro et al. 2012).

It is clear that preexisting stress facilitates epileptogenesis by a number of known provocateurs, such as status epilepticus, head trauma, or kindling in the laboratory when they serve as a second hit. It is not established clearly that stress is a sufficient hit by itself to produce spontaneous seizure. Another question is can stress serve as a second hit when there is a preexisting genetic/structural predisposition to epilepsy and associated comorbidities. This seems likely, based on anecdotal experience from the clinic. This idea is quite testable in animals with a mild epileptic phenotype caused by genetic manipulations.

In the other direction, stereotactic injection of kainic acid in area CA1 of the rat dorsal hippocampus not only produced seizures and selective lesion in the CA3, but indirectly stimulated the HPA axis producing a significant elevation in circulating CORT (Daniels et al. 1990). Increased plasma CORT results have also resulted from electrical stimulation of the dorsal hippocampus (Casady and Taylor 1976). Rats in which chronic epilepsy is produced by lithium-pilocarpine treatment manifest a hyperactive HPA axis function as evidenced by failure to respond to a DEX challenge with depression CORT and an exaggerated CORT response to a systemic injection of $\mathrm{CRH}$ and manifest depressive behaviors; the severity of the behavioral aberrations correlated with the extent of HPA axis dysfunction (Mazarati et al. 2009; Inostroza et al. 2012). Traumatic brain injury (TBI) in rats can model posttraumatic epilepsy (Kharatishvili et al. 2006). Rats subjected to TBI also show HPA axis hyperactivity (Griesbach et al. 2011), and the evolution of behavioral abnormalities has been documented (Pandey et al. 2009; Shultz et al. 2012; Kuo et al. 2013).

The data presented thus far show that epilepsy can play the role of a stressful stimulus and 
lead to HPA axis dysfunction and depression, whereas the HPA axis dysregulation can further exacerbate the severity of epilepsy, creating a positive feedback loop or vicious cycle. It was also described earlier that early life experience can further amplify the seizure-induced increase in CORT (Lai et al. 2006). This raises the possibility that inhibitors of cortisol synthesis or glucocorticoid receptor antagonists may represent an attractive option to supplement antiseizure and antidepressant therapy to interrupt the positive feedback loop, and improve the response to conventional pharmacotherapy (Dinan 2001).

\section{Impairment of Serotonergic Transmission}

Serotonergic innervation is mainly derived from the raphe nucleus in the dorsal brain stem. Projections from this nucleus to the prefrontal cortex and hippocampus are important in the regulation of mood. The release of 5-HT is regulated by short-feedback loop autoinhibitory fibers that activate 5-HT1A autoreceptors. The activation of these receptors leads to a hyperpolarizing response and inhibits the firing of the serotonergic neurons that project to distant targets, thus serving a negative feedback loop function (Riad et al. 2000; RichardsonJones et al. 2010). If the 5-HT1A receptors become hyperactive, 5-HTrelease would be compromised and result in depression. Genetically modified mice with enhanced 5-HT1A receptors show vulnerability to depression (Richardson-Jones et al. 2010), whereas mice inbred for depressive traits display exaggerated response to 5-HT1A receptor stimulation. Consistent with those observations, selective pharmacologic blockade of presynaptic raphe 5-HT1A receptors produced an antidepressant effect and improves performance of epileptic rats in the FST (Mazarati et al. 2010). On the other hand, depression may also result from compromised activity at the forebrain postsynaptic 5-HT1A receptors that form the targets for the serotonergic innervation from the raphe. Selective stimulation of postsynaptic 5-HT1A receptors ameliorates experimental models of depression (Llado-Pelfort et al. 2010; Zhou et al. 2014).
The involvement of the serotonergic system in seizures and epilepsy is well established. Genetic epilepsy-prone rats (GEPRs) show abnormalities in many aspects of serotonergic function, including 5-HT synthesis, transport, and receptor binding (Dailey et al. 1992; Statnick et al. 1996a,b). Enhanced vulnerability to, and higher mortality from, seizures induced by kainic acid were seen in mice lacking 5-HT1A receptors in the hippocampus compared with the wild-type control mice (Sarnyai et al. 2000). In experiments involving hippocampal slice preparations, specific activation of 5-HT1A receptors abolished epileptiform activity induced by picrotoxin (Lu and Gean 1998) or bicuculline (Salgado-Commissariat and Alkadhi 1997). In in vivo rat experiments, the SSRI, fluoxetine, had an ameliorative effect on kindled seizures (Siegel and Murphy 1979), spontaneous seizures that followed pilocarpine-induced status epilepticus (Hernandez et al. 2002; Mazarati et al. 2008), as well as lowered interictal neuronal excitability as measured by after-discharge threshold and after-discharge duration (Mazarati et al. 2008). Modest anticonvulsant effects have also been shown for another SSRI, citalopram, in rats rendered epileptic by systemic kainic acid treatment (Vermoesen et al. 2012).

Studies involving rats with chronic epilepsy after lithium-pilocarpine treatment, depression-like behaviors in the taste preference test and immobility in the FST correlate with compromised serotonergic tone in the raphe-forebrain projection (Pineda et al. 2011). The experiments revealed enhanced 5-HT1A autoreceptor receptor function in the raphe, resulting in compromised evoked release of 5-HT as measured in the hippocampus on raphe stimulation and at the same time a down-regulation of the postsynaptic 5-HT1A in the hippocampus. Immobility in the FST could be reduced by intra-raphe injection of selective 5-HT1A antagonist or stimulation of hippocampal 5HT1A receptors in the hippocampus by local injection of an agonist (Pineda et al. 2011). These findings show multiple mechanisms are at play in mediating plasticity in the serotonergic system in experimental epilepsy that is associated with depression. 
The connection between epileptogenesis and the development of compromised serotonergic tone accompanying depression may be subserved by the maladaptation in the HPA axis. Abnormally elevated levels of glucocorticoids up-regulate 5-HT1A autoreceptors in the raphe, diminishing serotonergic outflow (Bellido et al. 2004; Judge et al. 2004). Local injections of a glucocorticoid receptor mifepristone into the raphe improved the serotonergic output and performance in the FST in epileptic animals with concurrent depression after lithium-pilocarpine status epilepticus (Pineda et al. 2011). The hyperactive HPA system not only serves as a link between epilepsy and depression, but also provides for a positive feedback system modifying the serotonergic system and, in turn, exacerbating both depression and epilepsy.

\section{Disturbances in Opioid Neurotransmission}

As a general rule, opioids tend to inhibit neurotransmitter release in the central nervous system (CNS). However, in the hippocampus, endogenic MOR and DOR agonists like enkephalins exert their action selectively on GABAergic interneurons, resulting in excitation of pyramidal neurons (Zieglgänsberger et al. 1979). On the other hand, KOR agonists like dynorphins exert an inhibitory effect presynaptically on glutamate release at the performant path-dentate granule cell synapse (Wagner et al. 1993). Despite these opposite effects on excitability, the net effect may be that the release of endogenous opioids triggered by seizures contributes to elevating the seizure threshold, and their tone also contributes to the postictal state (Tortella 1988). Indeed, anticonvulsant effects of opioid peptides have been shown against maximal electroshock seizures in the rat (Berman and Adler, 1984), and enkephalins have been shown to oppose the epileptiform EEG changes induced by intraventricular administration of corticotropin release factor (Pieretti et al. 1990). In a number of experimental paradigms, transient changes in opioid peptides have been shown following seizures (Simmons and Chavkin 1996). Overall, it is not clear whether seizure-induced changes in opioid-signaling pathways provide a positive feedback to exacerbate depression. Indeed, although an increase in dynorphin levels during prolonged exposure to stress may produce learned helplessness, dysphoria, and depression, whereas the release of $\beta$-endorphins in the amygdala in response to stress seems to inhibit the overactivation of HPA axis (Bali et al. 2015). In this manner, the opioid system may function more as a negative feedback loop in connecting epilepsy and depression.

\section{Role of Neuroinflammation}

Administration of IL- $1 \beta$ or the bacterial endotoxin, lipopolysaccharide, to mice increased the time spent immobile in the FST and the tail suspension test (Dunn and Swiergiel 2005). Central administration of IL-1 $\beta$ also increased plasma CORT levels (Parsadaniantz et al. 1997), and has been shown, in vitro, to suppress the firing of raphe serotonergic neurons (Brambilla et al. 2007; Vezzani et al. 2011, 2013). Mice deficient in the interleukin receptor 1 (IL$1 \mathrm{R} 1^{-/-}$) displayed an elevated threshold for the induction of febrile seizures (Dubé et al. 2005). In models of TLE, IL-1 $\beta$, as well as its receptor (IL-1R1) are overexpressed in the hippocampus in models of TLE in rodents (Ravizza et al. 2008a,b). Inhibition of the IL-1 $\beta$-synthesizing enzyme, caspase-1, impaired kindling epileptogenesis (Ravizza et al. 2008b). Pharmacological inhibition of either IL-1 $\beta$ directly by the peptide antagonist anakinra or the inhibition of caspase-1, achieved neuroprotection in two models of experimental status epilepticus (Noe et al. 2013), whereas epileptogenesis was not sufficiently mitigated, the latter probably related to the administration of those agents well into the course of status epilepticus. Overall, inflammation, especially IL- $1 \beta$, also seems to participate in a positive feedback loop. Thus, the enhanced IL-1 $\beta$ signaling may play a role in treatment resistant depression. Consistent with that idea is the finding that fluoxetine resistance in epileptic rats (Mazarati et al. 2008) could be overcome by low dose treatment with an antagonist of IL-1R1 by normalizing the 5-HT1A autoreceptor function (Pineda et al. 2012). 


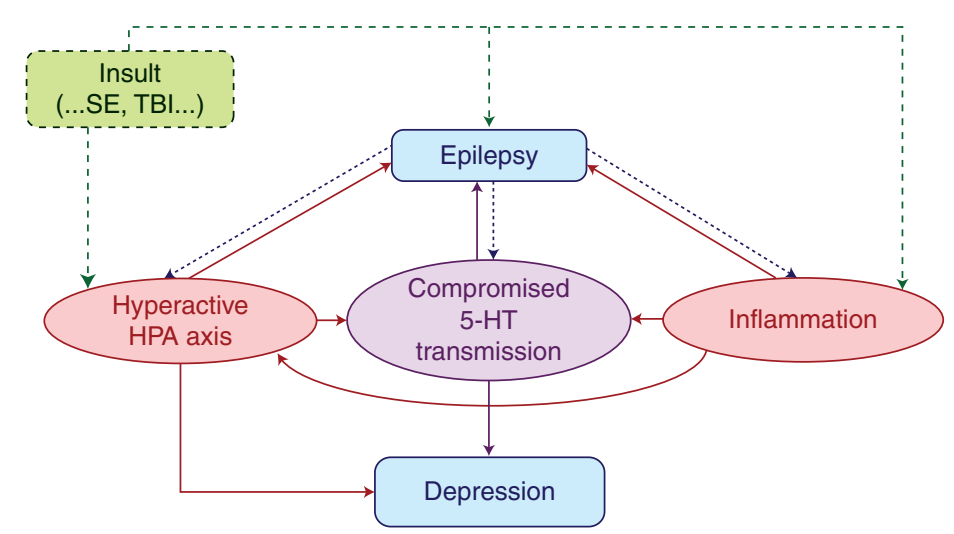

Figure 1. Interactions between neuroendocrine, neurotransmitter, and inflammatory mechanisms. HPA, hypothalamic-pituitary-adrenal; 5-HT, serotonin; SE, status epilepticus; TBI, traumatic brain injury.

\section{CONCLUDING REMARKS}

The data reviewed the idea that both epilepsy and depression are linked by a number of systems, such as the HPA axis, the immune system, and neurotransmitter systems. In this discussion, we focused on depression as the comorbidity and the serotonergic system as the most immediately relevant neurotransmitter system. Emerging findings suggest noradrenergic systems to be an important link between epilepsy and ADHD, another common comorbidity in PWE (Pineda et al. 2014).

Figure 1 is a schematic to illustrate how both inflammation and the HPA axis serve to link epilepsy and depression, both directly, and by leveraging neurotransmitter mechanisms. The presence of positive feedback loops ("vicious circles") makes it difficult to identify primary and secondary, although we have given the slant of visualizing epilepsy at the primary disorder and depression as a consequence, disclosing the bias of the epilepsy specialist and scientist. Indeed, it is possible to have an underlying cause, genetic or acquired (status epilepticus, traumatic brain injury, autoimmune disorder involving the brain), in which epilepsy and depression (or other comorbidities involving attention, cognition) may develop independently and concurrently, but can also exacerbate each other by the mechanisms reviewed here. Thus, in animal models, creation of one disorder (epilepsy) may give rise to another (depression, ADHD); be- cause we know the comorbidity did not preexist, we can conclude that the deliberate creation of one disorder (epilepsy) resulted in the emergence also of the other (the comorbidity of depression). The pathways delineated in Figure 1 show how each disorder can influence and exacerbate the other, thus reconciling laboratory observations with the findings from epidemiologic studies. The study of these intertwined mechanisms serves to both identify novel biomarkers and novel targets for intervention. Less is known about the role of the opioid system (not included in the figure), despite the tantalizing and teleologic perspective that if it evolved to help the organism adapt to pain and, especially stress, it may represent a negative feedback system with the promise of ameliorating both epilepsy and depression. At the moment, this is much farther removed form a therapeutic realm, compared with manipulations of the inflammatory system, the HPA axis, or the neurotransmitter-the last mentioned representing the road well traveled.

\section{ACKNOWLEDGMENTS}

A.M. is supported by National Institutes of Health (R01NS065783) and a research grant from the Today and Tomorrow Children's Fund. We also acknowledge generous support to R.S. by the Sudha Neelakantan and Venky Harinarayan Charitable Fund. 


\section{REFERENCES}

Adelow C, Anderson T, Ahlbom A, Tomson T. 2012 Hospitalization for psychiatric disorders before and after onset of unprovoked seizures/epilepsy. Neurology 78: $396-401$.

Aisa B, Tordera R, Lasheras B, Del Rio J, Ramirez MJ. 2007 Cognitive impairment associated to HPA axis hyperactivity after maternal separation in rats. Psychoneuroendocrinology 32: 256-266.

Albert PR, Benkelfat C. 2012. The neurobiology of depression-Revisiting the serotonin hypothesis. II: Genetic, epigenetic and clinical studies. Philos Trans $R$ Soc Lond B Biol Sci 368: 20120535.

Albert PR, Benkelfat C, Descarries L. 2012. The neurobiology of depression-Revisiting the serotonin hypothesis. I: Cellular and molecular mechanisms. Philos Trans R Soc Lond B Biol Sci 367: 2378-2381.

Alper KR, Schwartz KA, Kolts RL, Khan A. 2007. Seizure incidence in psychopharmacological clinical trials: An analysis of Food and Drug Administration (FDA) summary basis of approval reports. Biol Psychiatry 62: 345354.

Bajbouj M, Lisanby SH, Lang UE, Danker-Hopfe H, Heuser I, Neu P. 2006. Evidence for impaired cortical inhibition in patients with unipolar major depression. Biol Psychiatry 59: 395-400.

Bali A, Randhawa PK, Jaggi AS. 2015. Stress and opioids Role of opioids in modulating stress-related behavior and effect of stress on morphine conditioned place preference. Neurosci Biobehav Rev 51: 138-150.

Baune BT, Dannlowski U, Domschke K, Janssen DG, Jordan MA, Ohrmann P, Bauer J, Biros E, Arolt V, Kugel H, et al. 2010. The interleukin-1 $\beta$ (IL1B) gene is associated with failure to achieve remission and impaired emotion processing in major depression. Biol Psychiatry 67: 543549.

Bellido I, Hansson AC, Gomez-Luque AJ, Andbjer B, Agnati LF, Fuxe K. 2004. Corticosterone strongly increases the affinity of dorsal raphe 5-HT1A receptors. Neuroreport 15: $1457-1459$.

Bench CJ, Friston KJ, Brown RG, Frackowiak RS, Dolan RJ 1993. Regional cerebral blood flow in depression measured by positron emission tomography: The relationship with clinical dimensions. Psychol Med 23: 579590 .

Berman EF, Adler MW. 1984. The anticonvulsant effect of opioids and opioid peptides against maximal electroshock seizures in rats. Neuropharmacology 23: 367371.

Berman RM, Cappiello A, Anand A, Oren DA, Heninger GR, Charney DS, Krystal JH. 2000. Antidepressant effects of ketamine in depressed patients. Biol Psychiatry 47: $351-354$.

Bernardino L, Xapelli S, Silva AP, Jakobsen B, Poulsen FR Oliveira CR, Vezzani A, Malva JO, Zimmer J. 2005. Modulator effects of interleukin-1 $\beta$ and tumor necrosis factor- $\alpha$ on AMPA-induced excitotoxicity in mouse organotypic hippocampal slice cultures. J Neurosci 25: 734-44.

Bezzi P, Domercq M, Brambilla L, Galli R, Schols D, De Clercq E, Vescovi A, Bagetta G, Kollias G, Meldolesi J, et al. 2001. CXCR4-activated astrocyte glutamate release via TNF- $\alpha$ : Amplification by microglia triggers neurotoxicity. Nat Neurosci 4: 702-710.

Bilevicius E, Yasuda CL, Silva MS, Guerreiro CA, LopesCendes I, Cendes F. 2010. Antiepileptic drug response in temporal lobe epilepsy: A clinical and MRI morphometry study. Neurology 75: 1695-1701.

Boer K, Jansen F, Nellist M, Redeker S, van den Ouweland AM, Spliet WG, van Nieuwenhuizen O, Troost D, Crino PB, Aronica E. 2008. Inflammatory processes in cortical tubers, and subependymal giant cell tumors of tuberous sclerosis complex. Epilepsy Res 78: 7-21.

Borkowska P, Kucia K, Rzezniczek S, Paul-Samojedny M, Kowalczyk M, Owczarek A, Suchanek R, Medrala T, Kowalski J. 2011. Interleukin-1 $\beta$ promoter $(-31 \mathrm{~T} / \mathrm{C}$ and $-511 \mathrm{C} / \mathrm{T})$ polymorphisms in major recurrent depression. J Mol Neurosci 44: 12-16.

Bowley MP, Drevets WC, Ongur D, Price JL. 2002. Low glial numbers in the amygdala in major depressive disorder. Biol Psychiatry 52: 404-412.

Brambilla D, Franciosi S, Opp MR, Imeri L. 2007. Interleukin-1 inhibits firing of serotonergic neurons in the dorsal raphe nucleus and enhances GABAergic inhibitory postsynaptic potentials. Eur J Neurosci 26: 1862-1869.

Bremner JD, Narayan M, Anderson ER, Staib LH, Miller HL, Charney DS. 2000. Hippocampal volume reduction in major depression. Am J Psychiatry 157: 115-118.

Bremner JD, Vythilingam M, Vermetten E, Nazeer A, Adil J, Khan S, Staib LH, Charney DS. 2002. Reduced volume of orbitofrontal cortex in major depression. Biol Psychiatry 51: 273-279.

Briellmann RS, Hopwood MJ, Jackson GD. 2007. Major depression in temporal lobe epilepsy with hippocampal sclerosis: Clinical and imaging correlates. J Neurol Neurosurg Psychiatry 78: 1226-1230.

Bromfield EB, Altshuler L, Leiderman DB, Balish M, Ketter TA, Devinsky O, Post RM, Theodore WH. 1992. Cerebral metabolism and depression in patients with complex partial seizures. Arch Neurol 49: 617-623.

Cambell S, Marriott M, Nahmias C, MacQueen G. 2004 Lower hippocampal volume in patients suffering from depression: A meta-analysis. Am J Psychiatry 161: $598-$ 607.

Caplan R, Siddarth P, Gurbani S, Hanson R, Sankar R, Shields WD. 2005. Depression and anxiety disorders in pediatric epilepsy. Epilepsia 46: 720-730.

Casady RL, Taylor AN. 1976. Effect of electrical stimulation of the hippocampus upon corticosteroid levels in the freely behaving, non-stressed rat. Neuroendocrinology 20: $68-78$

Castro OW, Santos VR, Pun RY, McKlveen JM, Batie M, Holland KD, Gardner M, Garcia-Cairasco N, Herman JP, Danzer SC. 2012. Impact of corticosterone treatment on spontaneous seizure frequency and epileptiform activity in mice with chronic epilepsy. PLoS ONE 7: e46044

Chang YT, Chen PC, Tsai IJ, Sung FC, Chin ZN, Kuo HT, Tsai CH, Chou IC. 2011. Bidirectional relation between schizophrenia and epilepsy: A population-based retrospective cohort study. Epilepsia 52: 2036-2042.

Coppen A. 1967. The biochemistry of affective disorders. Br J Psychiatry 113: 1237-1264. 
Cotter D, Mackay D, Chana G, Beasley C, Landau S, Everall IP. 2002. Reduced neuronal size and glial cell density in area 9 of the dorsolateral prefrontal cortex in subjects with major depressive disorder. Cereb Cortex 12: 386394.

Crespel A, Coubes P, Rousset MC, Brana C, Rougier A, Rondouin G, Bockaert J, Baldy-Moulinier M, Lerner-Natoli M. 2002. Inflammatory reactions in human medial temporal lobe epilepsy with hippocampal sclerosis. Brain Res 952: 159-169.

Crossin KL, Tai MH, Krushel LA, Mauro VP, Edelman GM. 1997. Glucocorticoid receptor pathways are involved in the inhibition of astrocyte proliferation. Proc Natl Acad Sci 94: 2687-2692.

Dailey JW, Mishra PK, Ko KH, Penny JE, Jobe PC. 1992. Serotonergic abnormalities in the central nervous system of seizure-naive genetically epilepsy-prone rats. Life Sci 50: $319-326$.

Daniels WM, Jaffer A, Engelbrecht AH, Russell VA, Taljaard JJ. 1990. The effect of intrahippocampal injection of kainic acid on corticosterone release in rats. Neurochem Res 15: 495-499.

Davies CH, Davies SN, Collingridge GL. 1990. Paired-pulse depression of monosynaptic GABA-mediated inhibitory postsynaptic responses in rat hippocampus. J Physiol 424: 513-531.

Dinan T. 2001. Novel approaches to the treatment of depression by modulating the hypothalamic-pituitary-adrenal axis. Hum Psychopharmacol 16: 89-93.

Dubé C, Vezzani A, Behrens M, Bartfai T, Baram TZ. 2005. Interleukin- $1 \beta$ contributes to the generation of experimental febrile seizures. Ann Neurol 57: 152-155.

Dunn AJ, Swiergiel AH. 2005. Effects of interleukin-1 and endotoxin in the forced swim and tail suspension tests in mice. Pharmacol Biochem Behav 81: 688-693.

Edwards E, King JA, Fray JC. 1999. Increased basal activity of the HPA axis and renin-angiotensin system in congenital learned helpless rats exposed to stress early in development. Int J Dev Neurosci 17: 805-812.

Elger CE, Schmidt D. 2008. Modern management of epilepsy: A practical approach. Epilepsy Behav 12: 501-539.

El Yacoubi M, Bouali S, Popa D, Naudon L, Leroux-Nicollet I, Hamon M, Costentin J, Adrien J, Vaugeois JM. 2003. Behavioral, neurochemical, and electrophysiological characterization of a genetic mouse model of depression. Proc Natl Acad Sci 100: 6227-6232.

Engel J Jr. 2013. Basic mechanisms of seizures and epilepsy. In Seizures and epilepsy, 2nd ed. (ed. Engel J Jr), pp. 99156. Oxford University Press, New York.

Epps SA, Tabb KD, Lin SJ, Kahn AB, Javors MA, Boss-Williams KA, Weiss JM, Weinshenker D. 2012. Seizure susceptibility and epileptogenesis in a rat model of epilepsy and depression co-morbidity. Neuropsychopharmacology 37: 2756-2763.

Ettinger AB, Weisbrot DM, Nolan EE, Gadow KD, Vitale SA, Andriola MR, Lenn NJ, Novak GP, Hermann BP. 1998. Symptoms of depression and anxiety in pediatric epilepsy patients. Epilepsia 39: 595-599.

Favale E, Rubino V, Mainardi P, Lunardi G, Albano C. 1995. The anticonvulsant effect of fluoxetine in humans. Neurology 45: 1926.
Favale E, Audenino D, Cocito L, Albano C. 2003. The anticonvulsant effect of citalopram as an indirect evidence of serotonergic impairment in human epileptogenesis. Seizure 12: 316-318.

Forsgren L, Nystrom L. 1990. An incident case-referent study of epileptic seizures in adults. Epilepsy Res 6: 66-81.

Gabilondo AM, Meana JJ, Garcia-Sevilla JS. 1995. Increased density of $\mu$-opioid receptors in the postmortem brain of suicide victims. Brain Res 682: 245-250

Garakani A, Martinez JM, Yehuda R, Gorman JM. 2013. Cerebrospinal fluid levels of glutamate and corticotropin releasing hormone in major depression before and after treatment. J Affect Disord 146: 262-265.

Gerner RH, Hare TA. 1981. CSF GABA in normal subjects and patients with depression, schizophrenia, mania, and anorexia nervosa. Am J Psychiatry 138: 1098-1101.

Gilliam FG, Santos J, Vahle V, Carter J, Brown K, Hecimovic H. 2004. Depression in epilepsy: Ignoring clinical expression of a neuronal network dysfunction? Epilepsia 45: $28-33$.

Gilliam FG, Maton BM, Martin RC, Sawrie SM, Faught RE, Hugg JW, Viikinsalo M, Kuzniecky RI. 2007. Hippocampal 1H-MRSI correlates with severity of depression symptoms in temporal lobe epilepsy. Neurology 68: 364368.

Gregus A, Wintink AJ, Davis AC, Kalynchuk LE. 2005. Effect of repeated corticosterone injections and restraint stress on anxiety and depression-like behavior in male rats. Behav Brain Res 156: 105-114.

Griesbach GS, Hovda DA, Tio DL, Taylor AN. 2011. Heightening of the stress response during the first weeks after a mild traumatic brain injury. Neuroscience 178: $147-158$.

Gross-Isseroff R, Dillon KA, Israeli M, Biegon A. 1990. Regionally selective increases in $\mu$-opioid receptor density in the brains of suicide victims. Brain Res 530: 312-316.

Hammers A, Asselin MC, Hinz R, Kitchen I, Brooks DJ, Duncan JS, Koepp MJ. 2007. Upregulation of opioid receptor binding following spontaneous epileptic seizures. Brain 130: 1009-1016.

Harden CL, Goldstein MA. 2002. Mood disorders in patients with epilepsy: Epidemiology and management. CNS Drugs 16: 291-302.

Hasler G, Bonwetsch R, Giovacchini G, Toczek MT, Bagic A, Luckenbaugh DA, Drevets WC, Theodore WH. 2007. 5$\mathrm{HT}(1 \mathrm{~A})$ receptor binding in temporal lobe epilepsy patients with and without major depression. Biol Psychiatry 62: $1258-1264$.

Heckers S, Stone D, Walsh J, Shick J, Koul P, Benes FM. 2002. Differential hippocampal expression of glutamic acid decarboxylase 65 and 67 messenger RNA in bipolar disorder and schizophrenia. Arch Gen Psychiatry 59: 521-529.

Hermann BP, Seidenberg M, Bell B, Woodard A, Rutecki P, Sheth R. 2000a. Comorbid psychiatric symptoms in temporal lobe epilepsy: Association with chronicity of epilepsy and impact on quality of life. Epilepsy Behav 1: 184-190.

Hermann BP, Seidenberg M, Bell B. 2000b. Psychiatric comorbidity in chronic epilepsy: Identification, conse- 
quences, and treatment of major depression. Epilepsia $\mathbf{4 1}$ $31-41$.

Hernandez EJ, Williams PA, Dudek FE. 2002. Effects of fluoxetine and TFMPP on spontaneous seizures in rats with pilocarpine-induced epilepsy. Epilepsia 43: 13371345.

Hesdorffer DC, Hauser WA, Annegers JF, Cascino G. 2000. Major depression is a risk factor for seizures in older adults. Ann Neurol 47: 246-249.

Hesdorffer DC, Ludvigsson P, Olafsson E, Gudmundsson G, Kjartansson O, Hauser WA. 2004. ADHD as a risk factor for incident unprovoked seizures and epilepsy in children. Arch Gen Psychiatry 61: 731-736.

Hesdorffer DC, Hauser WA, Ludvigsson P, Olafsson E, Kjartansson O. 2006. Depression and attempted suicide as risk factors for incident unprovoked seizures and epilepsy. Ann Neurol 59: 35-41.

Hesdorffer DC, Ishihara L, Mynepalli L, Webb DJ, Weil J, Hauser WA. 2012. Epilepsy, suicidality, and psychiatric disorders: A bidirectional association. Ann Neurol 72: $184-191$.

Holmes PV. 2003. Rodent models of depression: Reexamining validity without anthropomorphic inference. Crit Rev Neurobiol 15: 143-174.

Hu S, Sheng WS, Ehrlich LC, Peterson PK, Chao CC. 2000. Cytokine effects on glutamate uptake by human astrocytes. Neuroimmunomodulation 7: 153-159.

Inostroza M, Cid E, Menendez de la Prida L, Sandi C. 2012. Different emotional disturbances in two experimental models of temporal lobe epilepsy in rats. PLoS ONE 7: e38959.

Johnson EK, Jones JE, Seidenberg M, Hermann BP. 2004. The relative impact of anxiety, depression, and clinical seizure features on health-related quality of life in epilepsy. Epilepsia 45: 44-555.

Johnson SA, Fournier NM, Kalynchuk LE. 2006. Effect of different doses of corticosterone on depression-like behavior and HPA axis responses to a novel stressor. Behav Brain Res 168: 280-288.

Jones NC, Lee HE, Yang M, Rees SM, Morris MJ, O’Brien TJ, Salzberg MR. 2013. Repeatedly stressed rats have enhanced vulnerability to amygdala kindling epileptogenesis. Psychoneuroendocrinology 38: 263-270.

Judge SJ, Ingram CD, Gartside SE. 2004. Moderate differences in circulating corticosterone alter receptor-mediated regulation of 5-hydroxytryptamine neuronal activity. J Psychopharmacol 18: 475-483.

Jutkiewicz EM. 2006. The antidepressant-like effects of $\delta$ opioid receptor agonists. Mol Interv 6: 162-169.

Kanemoto K, Kawasaki J, Yuasa S, Kumaki T, Tomohiro O, Kaji R, Nishimura M. 2003. Increased frequency of interleukin-1 $\beta-511 \mathrm{~T}$ allele in patients with temporal lobe epilepsy, hippocampal sclerosis, and prolonged febrile convulsion. Epilepsia 44: 796-799.

Kanner AM. 2005. Depression in epilepsy: A neurobiologic perspective. Epilepsy Curr 5: 21-27.

Karst H, de Kloet ER, Joels M. 1999. Episodic corticosterone treatment accelerates kindling epileptogenesis and triggers long-term changes in hippocampal CA1 cells, in the fully kindled state. Eur J Neurosci 11: 889-898.
Kash SF, Johnson RS, Tecott LH, Noebels JL, Mayfield RD, Hanahan D, Baekkeskov S. 1997. Epilepsy in mice deficient in the $65-\mathrm{kDa}$ isoform of glutamic acid decarboxylase. Proc Natl Acad Sci 94: 14060-14065.

Kempton MJ, Salvador Z, Munafò MR, Geddes JR, Simmons A, Frangou S, Williams SC. 2011. Structural neuroimaging studies in major depressive disorder. Metaanalysis and comparison with bipolar disorder. Arch Gen Psychiatry 68: 675-690.

Kharatishvili I, Nissinen JP, McIntosh TK, Pitkänen A. 2006. A model of posttraumatic epilepsy induced by lateral fluid-percussion brain injury in rats. Neuroscience 140: 685-697.

Koepp MJ, Richardson MP, Brooks DJ, Duncan JS. 1998. Focal cortical release of endogenous opioids during reading-induced seizures. Lancet 352: 952-955.

Koepp MJ, Hammers A, Lawrence AD, Asselin MC, Grasby PM, Bench CJ. 2009. Evidence for endogenous opioid release in the amygdala during positive emotion. Neuroimage 44: 252-256.

Krishnadas R, Cavanagh J. 2012. Depression: An inflammatory illness? J Neurol Neurosurg Psychiatry 83: 495-502.

Kujirai T, Caramia MD, Rothwell JC, Day BL, Thompson PD, Ferbert A, Wroe S, Asselman P, Marsden CD. 1993. Corticocortical inhibition in human motor cortex. $J$ Physiol 471: 501-519.

Kumar G, Couper A, O’Brien TJ, Salzberg MR, Jones NC, Rees SM, Morris MJ. 2007. The acceleration of amygdala kindling epileptogenesis by chronic low-dose corticosterone involves both mineralocorticoid and glucocorticoid receptors. Psychoneuroendocrinology 32: 834-842.

Kumar G, Jones NC, Morris MJ, Rees S, O’Brien TJ, Salzberg MR. 2011. Early life stress enhancement of limbic epileptogenesis in adult rats: Mechanistic insights. PLOS ONE 6: e24033.

Kuo JR, Cheng YH, Chen YS, Chio CC, Gean PW. 2013. Involvement of extracellular signal regulated kinases in traumatic brain injury-induced depression in rodents. $J$ Neurotrauma 30: 1223-1231.

Lai MC, Holmes GL, Lee KH, Yang SN, Wang CA, Wu CL, Tiao MM, Hsieh CS, Lee CH, Huang LT. 2006. Effect of neonatal isolation on outcome following neonatal seizures in rats-The role of corticosterone. Epilepsy Res 68: $123-136$.

Lefaucheur JP, Lucas B, Andraud F, Hogrel JY, Bellivier F, Del Cul A, Rousseva A, Leboyer M, Paillère-Martinot ML. 2008. Inter-hemispheric asymmetry of motor corticospinal excitability in major depression studied by transcranial magnetic stimulation. J Psychiatr Res 42: 389-398.

Levinson AJ, Fitzgerald PB, Favalli G, Blumberger DM, Daigle M, Daskalakis ZJ. 2010. Evidence of cortical inhibitory deficits in major depressive disorder. Biol Psychiatry 67: $458-464$.

Lewis A. 1934. Melancholia: A historical review. J Mental Sci 80: $1-42$.

Lin JJ, Salamon N, Lee AD, Dutton RA, Geaga JA, Hayashi KM, Luders E, Toga AW, Engel J Jr, Thompson PM. 2007. Reduced neocortical thickness and complexity mapped in mesial temporal lobe epilepsy with hippocampal sclerosis. Cereb Cortex 17: 2007-2018. 
Llado-Pelfort L, Assie MB, Newman-Tancredi A, Artigas F, Celada P. 2010. Preferential in vivo action of F15599, a novel 5-HT(1A) receptor agonist, at postsynaptic 5HT(1A) receptors. Br J Pharmacol 160: 1929-1940.

López JF, Chalmers DT, Little KY, Watson SJ. 1998. Regulation of serotonin ${ }_{1 \mathrm{~A}}$, glucocorticoid, and mineralocorticoid receptor in rat and human hippocampus: implications for the neurobiology of depression. Biol Psychiatry 43: $547-573$.

Lothe A, Didelot A, Hammers A, Costes N, Saoud M, Gilliam F, Ryvlin P. 2008. Comorbidity between temporal lobe epilepsy and depression: A $\left[{ }^{18} \mathrm{~F}\right] \mathrm{MPPF}$ PET study. Brain 131: 2765-2782.

Lu KT, Gean PW. 1998. Endogenous serotonin inhibits epileptiform activity in rat hippocampal CA1 neurons via 5-hydroxytryptamine ${ }_{1 \mathrm{~A}}$ receptor activation. Neuroscience 86: $729-737$.

Mague SD, Pliakas AM, Todtenkopf MS, Tomasiewicz HC, Zhang Y, Stevens WC Jr, Jones RM, Portoghese PS, Carlezon WA Jr. 2003. Antidepressant-like effects of $\kappa$-opioid receptor antagonists in the forced swim test in rats. $J$ Pharmacol Exp Ther 305: 323-330.

Martinez A, Finegersh A, Cannon DM, Dustin I, Nugent A, Herscovitch P, Theodore WH. 2013. The 5-HT1A receptor and 5-HT transporter in temporal lobe epilepsy. Neurology 80: 1465-1471.

Mayberg HS, Sadzot B, Meltzer CC, Fisher RS, Lesser RP, Dannals RF, Lever JR, Wilson AA, Ravert HT, Wagner HN Jr, et al. 1991. Quantification of $\mu$ and non- $\mu$ opiate receptors in temporal lobe epilepsy using positron emission tomography. Ann Neurol 30: 3-11.

Mazarati A, Siddarth P, Baldwin RA, Shin D, Caplan R, Sankar R. 2008. Depression after status epilepticus: Behavioural and biochemical deficits and effects of fluoxetine. Brain 131: 2071-2083.

Mazarati AM, Shin D, Kwon YS, Bragin A, Pineda E, Tio D, Taylor AN, Sankar R. 2009. Elevated plasma corticosterone level and depressive behavior in experimental temporal lobe epilepsy. Neurobiol Dis 34: 457-461.

Mazarati AM, Pineda E, Shin D, Tio D, Taylor AN, Sankar R. 2010. Comorbidity between epilepsy and depression: Role of hippocampal interleukin-1 $\beta$. Neurobiol Dis 37: 461-467.

Muller N, Myint AM, Schwarz MJ. 2011. Inflammatory biomarkers and depression. Neurotox Res 19: 308-318

Nestler EJ, Barrot M, DiLeone RJ, Eisch AJ. 2002. Neurobiology of depression. Neuron 34: 13-25.

Noe FM, Polascheck N, Frigerio F, Bankstahl M, Ravizza T, Marchini S, Beltrame L, Banderó CR, Löscher W, Vezzani A. 2013. Pharmacological blockade of IL-1 $\beta /$ IL-1 receptor type 1 axis during epileptogenesis provides neuroprotection in two rat models of temporal lobe epilepsy. Neurobiol Dis 59: 183-193.

Novati A, Roman V, Cetin T, Hagewoud R, den Boer JA, Luiten PG, Meerlo P. 2008. Chronically restricted sleep leads to depression-like changes in neurotransmitter receptor sensitivity and neuroendocrine stress reactivity in rats. Sleep 31: 1579-1585.

Oguz A, Kurul S, Dirik E. 2002. Relationship of epilepsyrelated factors to anxiety and depression scores in epileptic children. J Child Neurol 17: 37-40.
Öngür D, Drevets WC, Price JL. 1998. Glial reduction in the subgenual prefrontal cortex in mood disorders. Proc Natl Acad Sci 95: 13290-13295.

Pandey DK, Yadav SK, Mahesh R, Rajkumar R. 2009. Depression-like and anxiety-like behavioural aftermaths of impact accelerated traumatic brain injury in rats: A model of comorbid depression and anxiety? Behav Brain Res 205: 436-442.

Parsadaniantz SM, Batsche E, Gegout-Pottie P, Terlain B, Gillet P, Netter P, Kerdelhué B. 1997. Effects of continuous infusion of interleukin- $1 \beta$ on corticotropin releasing hormone $(\mathrm{CRH}), \mathrm{CRH}$ receptors, proopiomelanocortin gene expression and secretion of corticotropin, $\beta$ endorphin and corticosterone. Neuroendocrinology 65: 53-63.

Pfeiffer A, Brantl V, Herz A, Emrich HM. 1986. Psychotomimesis mediated by $\mathrm{\kappa}$-opiate receptors. Science 233: 774-776.

Piazzini A, Canevini MP, Maggiori G, Canger R. 2001. Depression and anxiety in patients with epilepsy. Epilepsy Behav 2: 481-489.

Pieretti S, Ortolani E, Di Giannuario A, Loizzo A. 1990. Effects of endorphin derivatives on the EEG alterations induced by corticotropin releasing factor in the rabbit hippocampus. Pharmacol Res 22: 627-633.

Pineda EA, Hensler JG, Sankar R, Shin D, Burke TF, Mazarati AM. 2011. Plasticity of presynaptic and postsynaptic serotonin 1A receptors in an animal model of epilepsy-associated depression. Neuropsychopharmacology 36: 1305-1316.

Pineda EA, Hensler JG, Sankar R, Shin D, Burke TF, Mazarati AM. 2012. Interleukin- $1 \beta$ causes fluoxetine resistance in an animal model of epilepsy-associated depression. Neurotherapeutics 9: 477-485.

Pineda E, Jentsch JD, Shin D, Griesbach G, Sankar R, Mazarati A. 2014. Behavioral impairments in rats with chronic epilepsy suggest comorbidity between epilepsy and attention deficit/hyperactivity disorder. Epilepsy Behav 31: 267-75.

Ravizza T, Boer K, Redeker S, Spliet WG, van Rijen PC, Troost D, Vezzani A, Aronica E. 2006. The Il-1 $\beta$ system in epilepsy-associated malformations of cortical development. Neurobiol Dis 24: 128-143.

Ravizza T, Gagliardi B, Noe F, Boer K, Aronica E, Vezzani A. 2008a. Innate and adaptive immunity during epileptogenesis and spontaneous seizures: Evidence from experimental models and human temporal lobe epilepsy. Neurobiol Dis 29: 142-160.

Ravizza T, Noe F, Zardoni D, Vaghi V, Sifringer M, Vezzani A. 2008b. Interleukin converting enzyme inhibition impairs kindling epileptogenesis in rats by blocking astrocytic IL-1 $\beta$ production. Neurobiol Dis 31: 327-333.

Riad M, Garcia S, Watkins KC, Jodoin N, Doucet E, Langlois X, el Mestikawy S, Hamon M, Descarries L. 2000. Somatodendritic localization of 5-HT1A and preterminal axonal localization of 5-HT1B serotonin receptors in adult rat brain. J Comp Neurol 417: 181-194.

Richardson JS. 1991. Animal models of depression reflect changing views on the essence and etiology of depressive disorders in humans. Prog Neuropsychopharmacol Biol Psychiatry 15: 199-204. 
Richardson EJ, Griffith HR, Martin RC, et al. 2007 Structural and functional neuroimaging correlates of depression in temporal lobe epilepsy. Epilepsy Behav 10: 242-249.

Richardson-Jones JW, Craige CP, Guiard BP, Stephen A, Metzger KL, Kung HF, Gardier AM, Dranovsky A, David DJ, Beck SG, et al. 2010. 5-HT1A autoreceptor levels determine vulnerability to stress and response to antidepressants. Neuron 65: 40-52.

Salgado PC, Yasuda CL, Cendes F. 2010. Neuroimaging changes in mesial temporal lobe epilepsy are magnified in the presence of depression. Epilepsy Behav 19: 422427.

Salgado-Commissariat D, Alkadhi KA. 1997. Serotonin inhibits epileptiform discharge by activation of 5-HT1A receptors in CA1 pyramidal neurons. Neuropharmacology 36: 1705-1712.

Salzberg M, Taher T, Davie M, Carne R, Hicks RJ, Cook M, Murphy M, Vinton A, O’Brien TJ. 2006. Depression in temporal lobe epilepsy surgery patients: An FDG-PET study. Epilepsia 47: 2125-2130.

Sanacora G, Mason GF, Rothman DL, Behar KL, Hyder F, Petroff OA, Berman RM, Charney DS, Krystal JH. 1999. Reduced cortical $\gamma$-aminobutyric acid levels in depressed patients determined by proton magnetic resonance spectroscopy. Arch Gen Psychiatry 56: $1043-$ 1047.

Sanacora G, Mason GF, Rothman DL, Krystal JH. 2002. Increased occipital cortex GABA concentrations in depressed patients after therapy with selective serotonin reuptake inhibitors. Am J Psychiatry 159: 663-665.

Sanacora G, Mason GF, Rothman DL, et al. 2003. Increased cortical GABA concentrations in depressed patients receiving ECT. Am J Psychiatry 160: 577-579.

Sanacora G, Gueorguieva R, Epperson CN, Wu YT, Appel M, Rothman DL, Krystal JH, Mason GF. 2004. Subtypespecific alterations of $\gamma$-aminobutyric acid and glutamate in patients with major depression. Arch Gen Psychiatry 61: 705-713.

Sargent PA, Kjaer KH, Bench CJ, Rabiner EA, Messa C, Meyer J, Gunn RN, Grasby PM, Cowen PJ. 2000. Brain serotonin $1 \mathrm{~A}$ receptor binding measured by positron emission tomography with $\left[{ }^{11} \mathrm{C}\right]$ WAY-100635: Effects of depression and antidepressant treatment. Arch Gen Psychiatry 57: 174-180.

Sarnyai Z, Sibille EL, Pavlides C, Fenster RJ, McEwen BS, Toth M. 2000. Impaired hippocampal-dependent learning and functional abnormalities in the hippocampus in mice lacking serotonin ${ }_{1 \mathrm{~A}}$ receptors. Proc Natl Acad Sci 97: 14731-14736

Shah PJ, Ebmeier KP, Glabus MF, Goodwin GM. 1998. Cortical grey matter reductions associated with treatmentresistant chronic unipolar depression. Controlled magnetic resonance imaging study. Br J Psychiatry 172: 527 532.

Shamim S, Hasler G, Liew C, Sato S, Theodore WH. 2009. Temporal lobe epilepsy, depression, and hippocampal volume. Epilepsia 50: 1067-1071.

Sheline YI, Gado MH, Price JL. 1998. Amygdala core nuclei volumes are decreased in recurrent major depression. NeuroReport 9: 2023-2028.
Sheline YI, Sanghavi M, Mintun MA, Gado MH. 1999. Depression duration but not age predicts hippocampal volume loss in medically healthy women with recurrent major depression. J Neurosci 19: 5034-5043.

Shultz SR, Bao F, Omana V, Chiu C, Brown A, Cain DP. 2012. Repeated mild lateral fluid percussion brain injury in the rat causes cumulative long-term behavioral impairments, neuroinflammation, and cortical loss in an animal model of repeated concussion. J Neurotrauma 29: $281-294$.

Siegel J, Murphy GJ. 1979. Serotonergic inhibition of amygdala-kindled seizures in cats. Brain Res 174: 337-340.

Simmons ML, Chavkin C. 1996. Endogenous opioid regulation of hippocampal function. Int Rev Neurobiology 39: $145-198$.

Statnick MA, Dailey JW, Jobe PC, Browning RA. 1996a. Abnormalities in 5-HT1A and 5-HT1B receptor binding in severe-seizure genetically epilepsy-prone rats (GEPR9s). Neuropharmacology 35: 111-118.

Statnick MA, Dailey JW, Jobe PC, Browning RA. 1996b. Abnormalities in brain serotonin concentration, highaffinity uptake, and tryptophan hydroxylase activity in severe-seizure genetically epilepsy-prone rats. Epilepsia 37: $311-321$.

Taher TR, Salzberg M, Morris MJ, Rees S, O’Brien TJ. 2005. Chronic low-dose corticosterone supplementation enhances acquired epileptogenesis in the rat amygdala kindling model of TLE. Neuropsychopharmacology 30: 1610-1616.

Talmi M, Carlier E, Bengelloun W, Soumireu-Mourat B. 1995. Synergistic action of corticosterone on kainic acid-induced electrophysiological alterations in the hippocampus. Brain Res 704: 97-102.

Tebartz van Elst L, Woermann FG, Lemieux L, Trimble MR. 1999. Amygdala enlargement in dysthymia-A volumetric study of patients with temporal lobe epilepsy. Biol Psychiatry 461: 1614-1623.

Temkin O. 1971. The falling sickness. The John Hopkins Press, Baltimore, MD.

Theodore WH, Giovacchini G, Bonwetsch R, Bagic A, Reeves-Tyer P, Herscovitch P, Carson RE. 2006. The effect of antiepileptic drugs on 5-HT-receptor binding measured by positron emission tomography. Epilepsia 47: 499-503.

Toczek MT, Carson RE, Lang L, Ma Y, Spanaki MV, Der MG, Fazilat S, Kopylev L, Herscovitch P, Eckelman WC, et al. 2003. PET imaging of 5-HT1A receptor binding in patients with temporal lobe epilepsy. Neurology 60: 749756.

Tortella FC. 1988. Endogenous opioid peptides and epilepsy: Quieting the seizing brain? Trends Pharmacol Sci 9: 366-372.

Vermoesen K, Massie A, Smolders I, Clinckers R. 2012. The antidepressants citalopram and reboxetine reduce seizure frequency in rats with chronic epilepsy. Epilepsia 53: 870-878.

Vezzani A, French J, Bartfai T, Baram TZ. 2011. The role of inflammation in epilepsy. Nat Rev Neurol 7: 31-40.

Vezzani A, Aronica E, Mazarati A, Pittman QJ. 2013. Epilepsy and brain inflammation. Exp Neurol 244: 11-21. 
Viviani B, Bartesaghi S, Gardoni F, Vezzani A, Behrens MM Bartfai T, Binaglia M, Corsini E, Di Luca M, Galli CL, et al. 2003. Interleukin- $1 \beta$ enhances NMDA receptor-mediated intracellular calcium increase through activation of the Src family of kinases. J Neurosci 23: 8692-8700.

Wagner JJ, Terman GW, Chavkin C. 1993. Endogenous dynorphins inhibit excitatory neurotransmission and block LTP induction in the hippocampus. Nature 363: 451445.

Watson S, Gallagher P, Smith MS, Ferrier IN, Young AH 2006. The dex/CRH test-Is it better than the DST? Psychoneuroendocrinology 31: 889-894.

Zalsman G, Molcho A, Huang Y, Dwork A, Li S, Mann JJ. 2005. Postmortem $\mu$-opioid receptor binding in suicide victims and controls. J Neural Transm 112: 949-954.

Zarate CA Jr, Singh JB, Carlson PJ, Brutsche NE, Ameli R, Luckenbaugh DA, Charney DS, Manji HK. 2006. A randomized trial of an $\mathrm{N}$-methyl-D-aspartate antagonist in treatment-resistant major depression. Arch Gen Psychiatry 63: 856-864.

Zhou J, Cao X, Mar AC, Ding YQ, Wang X, Li Q, Li L. 2014. Activation of postsynaptic 5-HT receptors improve stress adaptation. Psychopharmacology (Berl) 231: 2067-2075.

Zieglgänsberger W, French ED, Siggins GR, Bloom FE. 1979 Opioid peptides may excite hippocampal pyramidal neurons by inhibiting adjacent inhibitory interneurons. Science 205: 415-416.

Zobel A, Wellmer J, Schulze-Rauschenbach S, Pfeiffer U, Schnell S, Elger C, Maier W. 2004. Impairment of inhibitory control of the hypothalamic pituitary adrenocortical system in epilepsy. Eur Arch Psychiatry Clin Neurosci 254: 303-311.

Zubieta JK, Ketter TA, Bueller JA, Xu Y, Kilbourn MR, Young EA, Koeppe RA. 2003. Regulation of human affective responses by anterior cingulate and limbic $\mu$-opioid neurotransmission. Arch Gen Psychiatry 60: 1145-1153. 


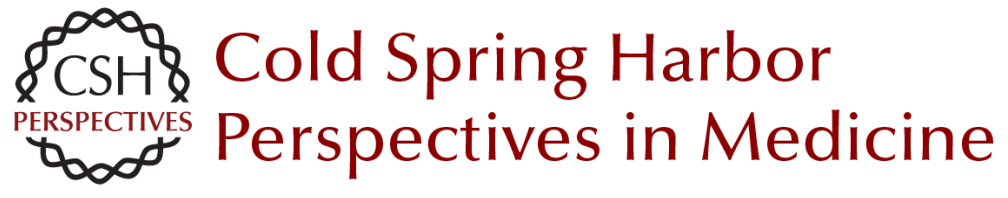

\section{Common Mechanisms Underlying Epileptogenesis and the Comorbidities of Epilepsy}

Andrey Mazarati and Raman Sankar

Cold Spring Harb Perspect Med 2016; doi: 10.1101/cshperspect.a022798

Subject Collection Epilepsy: The Biology of a Spectrum Disorder

The Epilepsy Spectrum: Targeting Future

Research Challenges

Gregory L. Holmes and Jeffrey L. Noebels

Role of Sodium Channels in Epilepsy

David I. Kaplan, Lori L. Isom and Steven Petrou

\section{Mechanisms of Action of Antiseizure Drugs and} the Ketogenic Diet

Michael A. Rogawski, Wolfgang Löscher and Jong M. Rho

Epilepsy and Autism

Ashura W. Buckley and Gregory L. Holmes

Immunity and Inflammation in Epilepsy

Annamaria Vezzani, Bethan Lang and Eleonora Aronica

Hyperpolarization-Activated Cyclic

Nucleotide-Gated (HCN) Channels in Epilepsy

Gary P. Brennan, Tallie Z. Baram and Nicholas $P$. Poolos

The Role of Calcium Channels in Epilepsy

Sanjeev Rajakulendran and Michael G. Hanna

Interneuron Transplantation as a Treatment for Epilepsy

Robert F. Hunt and Scott C. Baraban

\section{Common Mechanisms Underlying \\ Epileptogenesis and the Comorbidities of \\ Epilepsy \\ Andrey Mazarati and Raman Sankar}

The Diathesis-Epilepsy Model: How Past Events Impact the Development of Epilepsy and

Comorbidities

Christophe Bernard

Potassium Channels in Epilepsy

Rüdiger Köhling and Jakob Wolfart

\section{GABAergic Synchronization in Epilepsy Roustem Khazipov \\ Status Epilepticus \\ Syndi Seinfeld, Howard P. Goodkin and Shlomo Shinnar}

Neonatal and Infantile Epilepsy: Acquired and Genetic Models

Aristea S. Galanopoulou and Solomon L. Moshé

Epigenetics and Epilepsy
David C. Henshall and Katja Kobow

Microcircuits in Epilepsy: Heterogeneity and Hub

Cells in Network Synchronization

Anh Bui, Hannah K. Kim, Mattia Maroso, et al.

For additional articles in this collection, see http://perspectivesinmedicine.cshlp.org/cgi/collection/ 